$\underline{\text { Parallax }}$

$\underline{\text { Alistair Rider }}$

\title{
The Concreteness of Concrete Art
}

In the artistic and cultural lexicon of the short twentieth century, the term 'concrete' recurs repeatedly. A simple keyword search through any library or museum catalogue is likely to bring up hundreds of references to painters, sculptors, composers, graphic designers and poets who were working in dozens of cities around the world. High up on any list you would find mention of 'Konkrete Kunst' from Zürich, or from the socalled School of Ulm in Germany. ${ }^{1}$ The slim, single-issue magazine Art Concret, published in Paris in 1930, would also show up, as well, possibly, as 'Musique concrète'. ${ }^{2}$ In São Paulo, artists and poets united beneath the banner of 'Concretismo', although it would be mistaken to exclude the splinter group from Rio de Janeiro who preferred the term 'Neoconcretismo'. ${ }^{3}$ Meanwhile, in Buenos-Aires, Marxist artists had gathered under the name 'Concreto-Invención'. ' Search again and you will quickly come to references to 'concrete Poetry' in Scotland, or 'konkret poesi', as it was called in Sweden.

The word entered art discourse at some point during the 1920s in post-revolutionary Russia: 'Concreteness is the object in itself.[...] Concreteness is the sum of experience.[...] Concreteness is form', declared, for instance, a group of painters in the catalogue of the 'First Discussional Exhibition of Associations of Active Revolutionary Art' in $1924 .^{5}$ The suggestion that it might have been all of those things at once gives an indication of just how elastic the idea of a 'concrete art' could be, even from the outset. And over the course of the decades the word was stretched and pummelled to suit a not insubstantial spectrum of agendas and ideologies. The term is still used to this day, although less commonly by artists themselves. It has become more of a curatorial designation often promoted by museums whose mission it is to perpetuate the aesthetic. ${ }^{6}$

The era, however, when international interest in concrete art was at its greatest was during the 1950s to roughly the mid 1960s. We might take 1951 -- the year the Swiss artist and designer Max Bill won the international prize for sculpture at the first São Paulo Biennial for his work Tripartite Unity (1948-9) -- as the moment that ushered in the period of greatest engagement with concrete aesthetics on both sides of the Atlantic. ${ }^{7}$ Bill's winning contribution consisted of a single loop of stainless steel that had been parted and torqued into a complicated, upright form that enveloped an interior space. Standing at over a metre in height, it was interpreted as a bold endorsement of an artistic outlook that appeared both open to and informed by the latest innovations in post-war technology. Bill's approach to art would go on to have a substantial knock-on effect among Brazilian artists, and his influence undoubtedly contributed to the formation in São Paulo of Grupo Ruptura the following year. Led by Waldemar Cordeiro, they espoused a complete break with expressionist traditions within Brazilian painting. Later, in 1954, another collective established themselves in Rio, who called themselves Grupo Frente. The impact of these two movements was widespread, and informed the outlook not just of artists, but also contemporary poets, musicians and landscape designers, many of whom engaged in a fruitful intellectual exchange with their European counterparts. 
Pinpointing the period when interest began to wane is more controversial. Perhaps 1964, the year of the final issue of the Constructivist and De Stijl inspired journal, Structure: Annual on the New Art, might serve as one ending. ${ }^{8}$ The military coup in Brazil that same year, which upturned the country's political landscape and led to the withdrawal of numerous civil liberties, forced artists to renegotiate their relationship to their audience, and to rethink the role that art might serve in a society in which repression and state violence were increasingly the norm. In Brazil, the concrete aesthetic barely survived. Even in Western Europe, much of the earlier heat went out of the discussions. Supporters of concrete art became more defensive, and, within the art world at large, their conversations were increasingly marginalized. ${ }^{9}$ The ascendancy of American visual art during this era certainly had its role to play. It is well known that abstract artists in the United States, including Donald Judd or Frank Stella, actively distanced themselves from Europeans who had espoused the concrete moniker, in spite of the fact that their work covered surprisingly similar ground. ${ }^{10}$ Meanwhile, American critics ushered in an alternative discourse that revolved around concepts such as 'literalism', 'medium-specificity', or 'post-minimalism', and, as everlarger numbers of artists and intellectuals from outside the United States internalized the terminology of this new language, so a wider familiarity with the legacies of concrete art waned. Simultaneously, by around 1970, a number of those critics and artists who had endorsed concrete art a decade earlier were now pursuing their interests under different headings, such as information theory, or computer art, or New Tendencies. ${ }^{11}$

The question remains, then, what it meant to designate a work of art as concrete. The issue feels timely, thanks to the increasing recognition -- particularly among Anglophone historians of twentieth-century art -- that the discipline's research focus has still not engaged adequately with modernist traditions outside of Western Europe and North America. In the light of this, the concrete aesthetic, which otherwise might appear retardataire (at least within a more narrowly conceived and predominantly North American context), is attracting renewed levels of attention. It is increasing appreciated as a term that enjoyed genuine international currency during the early post-war period. Moreover, the lineages that concrete art forged generate significantly different vectors to those that have been canonized by more familiar modernist discourses. These are histories with different geographies -- ones in which Latin America, for instance, plays a much more prominent role. For many artists across South and Central America, 'the concrete' provided an invaluable resource by which they could fashion a geographically distinct mode of modernism through the 'cannibalization' of European precedents. ${ }^{12}$ The Brazilian poet Haroldo de Campos once testified to the importance of concretist aesthetics for writers in his country, for instance, by pointing out that authors, who, up to that point had been classified as working in a peripheral literature, were suddenly able to appropriate the entire linguistic code, 'reclaiming it as their whole patrimony'. It projected them onto an international, universal plane and made the Brazilian example the condition of possibility for conceptualizing the radical new poetic. ${ }^{13}$ Such was the sense of optimism that the concrete afforded. Thus, if it is our ambition to establish a stronger historical grasp of what was meant by the term, then these factors need to be taken into consideration. In any case, it would be a fundamental mistake to presume that there was ever somewhere in the world a quintessentially concrete art practice, which came to be increasingly diluted the further the concept travelled. The aesthetic was 
always inherently unstable, in spite of the seeming level-headed self-assurance of its rhetoric.

At the most basic level, the concrete was introduced into art discourse because it helped clarify a distinctively modern, experimental style of art, one that addressed the fundamentally new conditions of contemporary living. It was a means of describing the formal properties of an art that had turned its back on established or traditional styles and genres -- be they naturalism and figuration in the visual arts, or lyric verse in poetry, or melody and harmony in music. Defining a work as concrete was a way to accentuate the intensity, as well as the grounded nature, of the aesthetic experience.

In the visual arts, concrete art is almost always non-figurative. But to state that it is a subset of abstraction would be to misrepresent the way in which its early advocates, especially the Dutch painter Theo Van Doesburg and the Alsatian artist Hans or Jean Arp, came to define it. For them, the very term 'abstraction' was inadequate. It implied a sublation of sensory experience into a generalized realm of less tangible forms. Otto Carlsund, Van Doesburg, Jean Hélion, Léon Tutundjian and Marcel Wantz posed the rhetorical question in 1930 in their newly formed journal, Art Concret: were not a woman, a tree or a cow 'the concrete elements in painting'? Certainly not, they declared. 'A woman, a tree and a cow are concrete only in nature; in painting they are abstract, illusionistic, vague and speculative. ${ }^{14}$ This led them to offer what would become one of the most famous (and thoroughly tautological) definitions of the concrete in art: 'We speak of concrete and not abstract painting, because nothing is more concrete, more real than a line, a colour, a surface. ${ }^{15}$ Similarly, Arp wrote: 'we do not want to copy nature. we do not want to reproduce, we want to produce like a plant that produces a fruit and not to reproduce. we want to produce directly and not through interpretation.' From this it followed that 'as there is not the slightest trace of abstraction in this art, we call it: concrete art. ${ }^{16}$ Declaring a work of art to be concrete was, in essence, a way of emphasising the particularity and facticity of the art object as an object, rich in sensual immediacy. ${ }^{17}$

During the 1950s parallel assertions were also made by a range of poets who, informed by the terms of visual artists, fashioned a new mode of poetic diction that came to be known as 'concrete poetry'. Clearly, though, a point-to-point conversion of principles between visual and language-based media was never going to be possible, if only because words can never be said to be plain and simple objects. (Of course it is questionable whether a line or a colour are objects in any obvious sense, but clearly it is easier to believe in this fiction if you are dealing with non-linguistic signs, as opposed to writing proper.) Invariably words stand in for other things, and so can never be treated as existing outside the realm of signification. With this in mind, concrete poetry aspired to open up the signifying capacities of language by attending to words in innovative ways, often by removing them from sentences and paragraphs and setting them down in isolation. This process involved devoting much greater levels of attention to the visual appearance of text on the page than had been the norm for more traditional literary forms. As the German critic Max Bense explained, the semantic dimension of a concrete poem was not constituted by ordering words in linear, grammatical ways, but arose through 'visual connections'. Words were therefore now not mere 'supports of signification', but had become 'a concrete element of composition'. ${ }^{18}$ In this context the adjective 'concrete' seems to imply something similar to 'active', or 'substantive'. Indeed, it was on similar grounds that the Swiss 
poet Eugen Gomringer could propose that this new form of poetry treated words 'as a totality ... -- an intelligible object treated with concrete intentions as a useful thing'. ${ }^{19}$

It was in Portugese-speaking Brazil, however, that the concrete aesthetic can genuinely be said to have transformed the direction of the nation's literary scene, and given rise to a radical new form of poetics. The younger brother of Augusto de Campos, Haroldo, who was also a poet, testified to this when he insisted that the moment had come when this new tendency in literature had attained an equivalent level of self-confidence as it had already achieved in the visual arts. If, he wrote, a painter such as Cordiero could proclaim that concrete art was 'now as real as an apple', and not even bother to state that such work was non-figurative, then so too concrete poetry had attained a standing in which it no longer felt obliged to define itself as being in opposition to traditional modes of syntax. Instead, it held 'sway based on its own norms, based on its own conditions', settled as these were 'in the concrete roots of language. ${ }^{20}$

Tracking back to the visual arts, we might make a further observation about the assertiveness of the concretist aesthetic. Because once the claim had been made that this art celebrated the plain facticity of the object ('as real as an apple'), then it also became possible to assert that such work was ethically superior to those forms of art that might aspire to be representational. 'The raw material of representational art has always been illusion', we read, for instance, in the 1946 'Interventionist Manifesto' of the Argentinian group Arte Concreto-Invención, which was led by the painter Tomás Maldonado. ${ }^{21}$ And because they believed that their own angular shaped, stridently coloured canvases existed beyond the realm of representation, they saw their art as free from illusions of space, expression, reality and movement, enabling them to insist that concrete art 'makes people relate directly to real things not to fabrications. ${ }^{22}$ This dream of an encounter with an art object that would be direct and unmediated by language or representation is a powerful aspiration within modernism, and it was one in which concrete art was heavily invested.

Concrete artists, however, were not satisfied with merely celebrating the art object for its thing-like particularity, equivalent in status to other physical artefacts in the world. They also looked to authenticate the object in a realm that transcended the individual, and so would not be tied up with expressions of subjective emotions. They thus wanted to ground the object on impersonal, a priori laws, and aspired to make art that would be objective and universal. This explains the preponderance of articles on concrete art that were devoted to discussing themes such as 'science and technology in relation to art', or 'structure and art', or 'art and mathematics'. It also explains the renewal of interest among many concrete artists in the Dutch de Stijl painter, Georges Vantongerloo, whom they claimed as a precedent. Back in the early decades of the century, Vantongerloo had propounded the view that colour proportions could be mathematically determined. ${ }^{23}$ Piet Mondrian had dismissed this scientistic approach, believing that chromaticism was a much more intuitive matter. Yet Vantongerloo had insisted that art deserved to be ordered rationally, and would frequently give his works mathematical formulae for titles, as though his forms were the exemplification of a generalized, objective system. ${ }^{24}$ It was an ideal that subsequent artists would pursue further. Indeed, by far the longest piece of writing in the 1930 magazine, Art Concret, consisted of an essay by the painter Jean Hélion that was dedicated to 'Art and Mathematics', in which he insisted that just as the goal of mathematics was to 
concretize the laws of logic in formulas, so painting was committed to the equivalent task through the use of colour. ${ }^{25}$

However, colour proved a difficult phenomenon to objectify, and the tendency of the early concrete artists, particularly Van Doesburg in around 1930, was to restrict the paint palette to white and grey. For Van Doesburg it was the grid that served to convey a sense of art's objective rationalism. In his painting and graphic work from this period he divided the canvas into a lattice of 124 squares, and distributed planes of colour diagonally, with their proportions following a scaled ratio. IMAGE: Theo Van Doesburg, Arithmetic Composition, 1930, Kustmuseum Winterthur He believed that art should be preconceived in the mind, in order that the execution of the work could be realized as though it were a mere technical procedure. That meant using materials sparingly and attempting to conceal signs of handicraft, so as to ensure that facture did not detract attention from the underlying, intellectual rationale.

Following Van Doesburg's premature death from a heart attack in 1931, it was Bill who would go on to build on these methods the most systematically. An important series of lithographs, which he produced between 1935 and 1938, titled 'Fifteen Variations on a Single Theme', charts the way in which a geometrical configuration could be modified to form fifteen different visual realizations. IMAGE: Max Bill, quinze variations sur un même thème, 1935-38, lithograph, Museum of Modern Art, New York. The initial sequence consists of a single line that unfolds from a triangle, to a square, to a polygon, and so on, until it becomes an octagon. The position of the points formed at the angles of the arrangement then provided him with a set of coordinates that he used to generate an array of colour planes, designs of straight and curved lines, and spirals. To accompany each permutation he included a brief textual description, penned in value-neutral prose, which purported to rationalize the visual transformation that he had performed. ${ }^{26}$ The ambition was to cultivate an intellectualized and cerebral art practice, which invited viewers to regard each sequence in the series as the visualization of a transparent and logical progression.

It is unlikely, however, that contemporary professional mathematicians would have been greatly impressed by the sophistication of Bill's knowledge of geometry, as, indeed, the artist was all too aware. In a widely circulated essay, he explained that his aim was not to do 'mathematics in itself', but to explore a 'mathematical approach' to art. $^{27}$ Quite deliberately he kept his terms vague, and merely insinuated that there was an analogy between the development of mathematics and the natural sciences and the progress of art. Euclidian geometry and the laws of Archimedes were now widely understood to possess only limited validity, and, thanks to the likes of Lobatschevsky and Riemann, the horizons of knowledge had advanced, he wrote. Raphael and Seurat had created works in and of their time, but the new art 'has entered many domains to which it formally had no access. ${ }^{28}$ He was implying, in other words, that his art partook of the same spirit of research and discovery as the mathematical sciences, without stipulating with any clarity what those discoveries might be. Essentially, it was a bid for legitimacy: a way of claiming that contemporary concrete artists deserved a faculty seat at the modern technocratic university, alongside the theoretical physicists, electrical engineers and material scientists who were believed to be reshaping the horizons of possibility of western liberal democracies. Art's proper function, he insisted, was to make rational thought perceptible. 
It goes without saying that during the 1950s the allure of this stance for artists and intellectuals in German-speaking countries was considerable. The progressive agenda concrete art provided afforded many a resource for distancing themselves from the disastrous legacies of European fascism. Principles of rationalism, bathed in an aura of scientific optimism, were perceived as a healthy and necessary alternative to the emotive, myth-laden orientation that National Socialism had espoused for the arts. ${ }^{29}$

Concrete art was therefore two things at once. It was an outlook, or an orientation, that embraced objectivity and universalism as a positive and enabling force. But it also advocated that attention should be paid to the visual properties of a particular object. And the simultaneous focus on the specificity of formal attributes as well as grand, immaterial ideals had a tendency to lead to an unstable and potentially paradoxical discourse. Texts on concrete art are often inclined to leap from detailed practicalities to the most nebulous of terms. Take, once again, the journal Art Concret. Point three of the statement 'The Basis of Concrete Painting', which comes at the start of the publication, states that a painting should be constructed from planes and colours that have no other meaning than what they are by themselves. Yet this insistence on the non-symbolising status of individual painterly marks did not prevent Van Doesburg from stating, a few pages later, that art was 'the spiritual transformation of material. ${ }^{30}$ The suggestion that an object can be both itself and a transubstantiation of spirit attests to the somewhat roundabout and contradictory ways in which concrete artworks came to convey meaning.

Arp's art is a case in point. His decision to explain his work through reference to the concrete principle was undoubtedly inspired by Van Doesburg and Hélion, whom he knew well. ${ }^{31}$ Yet, being more sympathetic to the surrealists, he was less enamoured of the spirit of rationalism and technological progress. ${ }^{32}$ For this reason Arp is often excluded from wider discussions about concrete art, although in many respects his work raises the same interpretative challenges that we encounter in other manifestations of the concrete aesthetic.

Arp essentially reoriented an understanding of the concrete by identifying the creativity of art in natural, biological processes. 'I wanted to find another order, another value for man in nature', he wrote retrospectively in a publication from 1948. '[Man] was no longer to be the measure of all things, no longer to reduce everything to his own measure, but on the contrary, all things and man were to be like nature, without measure. ${ }^{33}$ Concrete art, in his understanding, should thus express the objective spirit of organic growth, as though its form were merely an inevitable process of coming into fruition, or a natural form of germination. For this reason, he believed that many of his sculptures could be sited out of doors, 'anonymous in the huge studio of nature'. ${ }^{34} \mathrm{He}$ even titled a series of associated works from the 1930s 'Sculptures to be Lost in the Forest'. ${ }^{35}$

Indeed Arp's numerous poetic explications have had a major impact on the way in which his works have been understood, especially those from around 1929 onwards, when he ceased working on his painted wood reliefs and began to sculpt directly in plaster. The resulting pieces were not particularly large in size, and occasionally consisted of several elements that rested on a larger one, which acted as the base. They bore titles such as Two Thoughts on a Navel (1932), or Metamorphosis (1935), while several were named Human Concretion. IMAGE: Hans Arp, Human 
Concretion, 1934, Fondation Arp, Clamart. Over the decades many writers have suggested that the biomorphic shapes of these sculptures look as though they are the outcome of an inner force, almost as if 'the work appears to grow organically from a nucleus', as William Rubin phrased it. ${ }^{36}$ Albert Elsen's remarks were also typical in this respect. He proposed that we regard Arp as a modeller, on the grounds that 'his forms are expansive and his beings pulsate rather than hold their breath. ${ }^{37}$ Such assertions therefore project a certain image of how the works were created: they imply that the sculptures were built up in an accretive fashion, analogous to the ways in which living organisms incrementally grow. Steven Harris recently took this reading further. He suggested that Arp's multi-part works, such as Head with Annoying Objects (1932), lend themselves to being physically manipulated by viewers, as part of an intimate, haptic encounter. He also accentuated that Arp's preferred material was plaster, a substance, he claimed, that lends itself naturally to handling. This then led him to Gaston Bachelard's poetic suggestion that the process of manually manipulating viscous matter is the hand's equivalent to dreaming, a proposition that enabled Harris to interpret the smooth surface of the sculptures as an expression of the spirit of involuntary, organic growth, 'pushing out from the inside', and thus incarnating 'an experience of unfolding ... that retains as well an element of the haptic. ${ }^{38}$

However, the strong image of tactility and subconscious growth that Arp's interpreters have emphasised -- drawn somewhat literally from the artist's statements -- sits uncomfortably with our knowledge of how Arp actually constructed his sculptures. The techniques Arp used for working in plaster were not dissimilar to those of Rodin, who was the first to declare sculptures made from this material to be finished works of art. Up to that point, it had been used largely as a mere studio resource for making cast copies. Unlike clay the material does not easily lend itself to kneading with the hands in the sense that Harris implied. When wet, it is too liquid to hold its shape, and once it hardens, it does so rapidly. Arp used rough, preformed blocks of the substance for his sculptures, which he sawed apart or glued together, adding additional layers where necessary in an improvisatory fashion. When these were dry, he used a rasp to sand his sculptures down to the smooth, continuous, undulating surfaces that would become his signature style. ${ }^{39}$ In other words, Arp's metaphorical claims that he was producing forms that appeared to have grown of their own accord bore little relation to the actual ad hoc and improvisatory process that went into creating the sculptures. This is barely surprising, yet emphasising this obliges us to be more precise about how it is that his sculptures convey meaning.

When the English sculptor Barbara Hepworth visited Arp's studio in Meudon in 1932 she recalled that initially she recoiled in horror at learning of Arp's preference for working in plaster. It seemed to her that the material lacked any sense of tactile pleasure, and only deadened the qualities 'of the sculptural idea'. Gradually, though, she came to the conclusion that plaster was advantageous to Arp. It was precisely because it was so lacking in sensual qualities that it facilitated the expression of his 'poetic idea'. ${ }^{40}$ The terminology was different, yet the rationale was surprisingly reminiscent of that which led Van Doesburg to advocate parsimony in the use of materials. Hepworth was implying, in other words, that the artist's interests perhaps lay less with the physical properties of specific objects than with the all-embracing formal principle to which they pointed. 
Indeed, several other commentators would later come to highlight Arp's morphological concerns, especially during the 1950s and 1960s. By then, his oeuvre had expanded to very sizeable proportions and the seemingly endless proliferation of biomorphic sculptures that emerged from his studio with each passing year prompted commentators to address the extraordinary stylistic continuity of his work with much more directness. IMAGE: Arp in his Meudon studio (photograph by Andre Villers), 1958. 'Arp is less interested in the fixed individual case', wrote Carola GiedionWelcker in 1957, for instance, 'than in the animated play of relationships, the sound and echoes within that dynamic order in which everything fluctuates'. ${ }^{41}$ Herbert Read also addressed the formal continuity of Arp's sculptures, drawing attention to the way in which an undulation or hollow in one work became the inspiration for another, as though one sculpture were a mere mutation of an earlier one. This led him to conclude that Arp's philosophy of natural growth was essentially a throwback to Goethe's proposition that all biological forms were a modification of a few basic types. ${ }^{42}$

Such observations were arguably a more accurate representation of Arp's work, in that they were not misled by the artist's assertions to present an inaccurate picture of how his sculptures had been created. They did, however, imply that the materiality of his works posed no fundamental resistance to the communication of his grand ideas about the philosophy of nature and life. The outcome was an odd impression of an awkwardly dematerialized art practice that was often presented as though it consisted only of shape-shifting apparitions. Giuseppe Marchioiri wrote, for instance, of how in Arp, the 'world of things enlarges to embrace phantasms ... which fail to dissolve in the atmosphere of a romantic dream and rather become bodies and figures in marble, stone, wood and bronze; and yet their fluid initial nucleus leaves a trace like something aerially vague'. ${ }^{43}$ The difficulty Marchiori faced was one of acknowledging the physical presence of the artist's sculptures, while also doing justice to what he perceived as the overarching idea. For him, the two simply do not seem to be reconcilable, leaving him shifting awkwardly between the material and immaterial realms.

In many respects this is symptomatic of the paradoxes interpreters face when engaging with concrete art. On the one hand, the demand of the artist was that the work be read as non-representational, and that the object stood purely for itself. On the other hand, its existence as art was justified by its larger significance, and this was one that was never capable of being contained entirely within its form, but was always spilling over into other realms. Concrete art might have claimed not to be figurative or representational, yet it did aspire to invoke a general truth, and policing the borderlines between iconicity and a more holistically conceived sense of signification proved difficult to sustain in the long run. The artists of Brazilian concretismo often exploited these contradictions. IMAGE: Lygia Clark, Composição, 1953, Collection Patricia Phelps de Cisneros. They saw the art of Bill and Gomringer as neither selfcontained nor self-evident, but as open-ended and rich in uncertainties. ${ }^{44}$ These they pursued, and, in the process, the concrete was translated into an intense, affective efflorescence.

\footnotetext{
${ }^{1}$ For a useful overview of European applications of the term 'concrete', see Lemoine, Art Concret, and Hoffmann, Die Idee Konkret.
} 
${ }^{2}$ Van Doesburg, et al, Art Concret. On musique concrète, see Schaeffer, In Search of a Concrete Music.

${ }^{3}$ For two classic surveys of the role played by concrete aesthetics in Latin American art, see Ades, Art in Latin America, and Ramírez and Olea, Inverted Utopias.

${ }^{4}$ See Crispiani, Objetos para transformar el mundo.

${ }^{5}$ Vilyams et al, 'Concretists', in Bowlt, Russian Art of the Avant-Garde, 240. Concrete art is frequently associated with Constructivism, another movement that arose in Russia in 1921, and for many authors the terms are used interchangeably. I avoid doing this here, mainly because by the post-war period international constructivism had come to refer to such a diverse array of artworks that its meaning has become much more imprecise. This is arguably less so for concrete art. For a recent discussion of the legacies of constructivism, see Taylor, After Constructivism.

${ }^{6}$ There are roughly twenty art museums across continental Europe, most of which are in German-speaking regions, that share a specific commitment to promoting concrete art. These institutions tend to have permanent collections that were endowed by a single collector who made 'the concrete' central to their acquisitions policy.

${ }^{7}$ For an account of the 1951 Biennial, see Merklinger, Die Biennale São Paulo, 12733

${ }^{8}$ The journal was edited by Joost Baljeu and Eli Bornstein. For a survey of the publication, see Jobse, De Stijl Continued.

${ }^{9}$ Following the student unrest in 1968 in West Germany, the high-minded values espoused by concrete art's most passionate advocate, Max Bill, were also subjected to increasing levels of scrutiny. See, for instance, Georg Radanowicz's 1969 film, 22 Fragen an Max Bill.

${ }^{10}$ For an example of Judd and Stella's stance towards contemporary abstraction in Europe, see Glazer, "Questions to Stella and Judd", in Art News (September 1966); reprinted in Battcock, Minimal Art, 148-9. For a discussion of Judd's strident refusal to associate himself with post-war geometric artists from Europe, see Bois, "1967c", 515-6. While several commentators on concrete and constructivist art have claimed American minimalists as fellow travellers, there are nonetheless significant differences between the two groups. American abstract artists such as Judd, Carl Andre, Mel Bochner or Sol LeWitt might have relied on ordering systems to construct their art, yet their use of seriality was not intended to invoke a higher level of rationalism, as was the case for Swiss artists such as Bill or Richard Paul Lohse. ${ }^{11}$ As Rachel Price has noted in her article "Object, non-object" 32), a number of Brazilian concrete artists went on to actively embrace new media, most notably Waldemar Cordeiro. In West Germany, the poet and philosopher Max Bense, who was central to discussion about concrete art, also inspired a number of engineers and artists to develop an 'algorithmic art' that relied on computer programming.

${ }^{12}$ See, for instance, Price, The Object of the Atlantic. In Brazil the use of the cannibal metaphor dates back to Oswald de Andrade polemical essay from 1928, who invoked it in order to define how modern Brazilians might fashion a modern national culture from their country's colonial origins.

${ }^{13}$ Haroldo de Campos, 'The Rule of Anthropophagy', 52.

${ }^{14}$ Van Doesburg et al, Art Concret, 2; reprinted in Baljeu, Theo van Doesburg, 181. Although the manifesto was signed by five artists, scholars are largely in agreement that van Doesburg was the prime mover in instigating the publication of the text.

${ }^{15}$ Van Doesburg et al, in Baljeu, Theo van Doesburg, 181.

${ }^{16}$ Arp, On My Way: Poetry and Essays, 1912-1947, 70. 
${ }^{17}$ This point is made particularly clearly by Galison in "Concrete Abstraction".

${ }^{18}$ Max Bense, in Rot, 21, special issue: 'konkrete poesie international'. My translation here is reliant on that provided by Perrone, in Seven Faces, 39.

${ }^{19}$ Gomringer, "Max Bill und die Konkrete Dichtung", in Festschrift zum 50.

Geburtstag von Max Bill; translated as "Max Bill and Concrete Poetry", in Solt, Concrete Poetry, 69.

${ }^{20}$ Augusto de Campos, "A Moeda Concreta de Fala" ("The Concrete Coin of Speech"), in Teoria da Poesia Concreta, 120. My translation draws on Bessa, "Word as Object: Concrete Poetry in Brazil, circa 1953", 92.

21 'Inventionist Manifesto", 146.

${ }^{22}$ Ibid., 146.

${ }^{23}$ See, for instance, Max Bill's introduction, in Georges Vantongerloo, 5.

${ }^{24}$ For a discussion of Vantongerloo's relationship to concrete artists, see Thomas, in Für eine neue Welt. "Aus der bewegten Geschichte der internationalen Künstlervereinigung Abstraction Création, Paris, 1931-1937".

${ }^{25}$ Hélion, 'Les Problèmes de l'art Concret: Art et Mathématiques', in Art Concret (1930), p. 5.

${ }^{26}$ For reproductions of the full series of lithographs, along with Bill's essay 'fifteen variations on a single theme', see Hüttinger, Max Bill, 68-77.

${ }^{27}$ Bill, "The Mathematical Approach", 66.

${ }^{28}$ Ibid., 66.

${ }^{29}$ The celebratory tenor of the collection of essays collated by the poet Eugen

Gomringer for Max Bill's fiftieth birthday provides a good indication of the ideological appeal of his art to his Swiss and German supporters. See in particular Gomringer's own contribution, which claims that 'unlike the rancour of all Picassolike arts' the concrete aesthetic was the first art of an international standard to adopt a positive disposition towards science and technology. In 'max bill und die konkrete dichtung', in Festscrift zum 50. Geburtstag von Max Bill, 59.

${ }^{30}$ Van Doesburg, "Définitions de l'art selon Doesbourg", Art Concret, 12.

${ }^{31}$ Jean Hélion writes that Arp found their position very alluring, yet shied away from the perceived violence of its authors' stance. See "Art Concret 1930: Four Painters and a Magazine", 128-33.

32 In a statement from 1954, ("Danger de Mort", 315). Arp proposed that in his view concrete art had 'its point of departure in the artist's unconscious' and expressed his reservations about the capacity of art to be grounded on a system of rationalism. 'Our generation takes immense pride in progress', he wrote. 'But progress will not help us advance towards the absolute.'

${ }^{33}$ Arp, 'I became More and More Removed', 237.

${ }^{34}$ Arp, 'Concrete Art', 139.

${ }^{35}$ On Arp's series 'Sculpture to be Lost in the Forest', see Andreotti, The Early Sculptures of Jean Arp, 206.

${ }^{36}$ Rubin, Dada, Surrealism, and their Heritage, 120. Astrid von Asten also writes in Hans Arp. Die Natur der Dinge that 'The Concretions [of the 1930s] are volumes that have become sculpture, in which a force pushing itself from the inside outward fills up the surface and forms the outlines.' See her essay 'Concretions', in Hans Arp. Die Natur der Dinge, 149.

${ }^{37}$ Elsen, Modern European Sculpture, 27.

${ }^{38}$ Harris, "Voluntary and Involuntary Sculpture", 27.

${ }^{39}$ For a detailed analysis of Arp's working methods, see Fischer, 16-31. 
${ }^{40}$ Hepworth, Carving and Drawings (1952), cited in Read, The Art of Jean Arp, 185.

${ }^{41}$ Carola Giedion-Welcker, Jean Arp, xiv.

${ }^{42}$ Read, The Art of Jean Arp, 88. It is likely that Read derived this observation from

F. G. Gregory, "Form in Plants" (57), which appeared in a volume of essays that emerged from a symposium that accompanied the 1951 exhibition, "Growth and Form", at the Institute of Contemporary Art in London. Read had written the Preface to this publication.

${ }^{43}$ Marchioiri, Arp, 49.

${ }^{44}$ Recent Latin American art scholars have emphasised this in their discussions of their reception. See, for instance, Ramírez, in "Between Corpus Solidum and quasicorpus" (274), who points out the ambivalences in Bill's understanding of the role of colour in his practice. It was an equivocation contemporary Brazilian artists exploited. In a similar vein, Olea, in "A Weekly Dose of Theory" mentions (218-9) that during the Second São Paulo Biennial in 1953 Bill confessed that he had conceived of the form for his sculpture Continuity (1946-7) before really knowing about the existence of the famous Möbius strip, on which it has often been claimed to be based. This detail fundamentally undermines the received assumption that his work was purely a self-evident manifestation of a pre-existing concept, and it opened the doors for Brazilian artists for a more flexible interpretation of the concrete aesthetic.

Bibliography

Ades, Dawn ed. Art in Latin America: The Modern Era, 1820-1980. London: Hayward Gallery, 1989.

Arp, Hans. On My Way: Poetry and Essays, 1912-1947. Translated by Ralph Manheim. New York: Wittenborn, Schultz, 1948.

Arp, Hans. "Danger de Mort"[1954]. In Marcel Jean, ed. Arp on Arp: Poems, Essays, Memories. New York: Viking Press, 1972, 315

Arp, Jean. "Concrete Art" [1944]. In Marcel Jean, ed. Arp on Arp: Poems, Essays Memories. New York: Viking Press, 1972, 139-140.

Arp, Jean. "I became More and More Removed from Aesthetics" [1948]. In Marcel Jean, ed. Arp on Arp: Poems, Essays Memories. New York: Viking Press, 1972, 237-38.

Baljeu, Joost. Theo Van Doesburg. New York: Macmillan, 1974.

Bense, Max, "XX". In Rot, 21 (May 1965) "konkrete poesie international", no page numbers.

Bessa, Antonio Sergio. "Word as Object: Concrete Poetry in Brazil, circa 1953", in Poesie-Konkret: Zur internationalen Verbreitung und Diversifizierung der Konkreten Poesie. Bremen: Museum für moderne Kunst, 2012.

Bill, Max, ed. Georges Vantongerloo. London, Marlborough Fine Arts, 1962. Bill, Max. "The Mathematical Approach in Contemporary Art", Structure, 2, 3 (1961), 64-66.

Bois, Yve-Alain, "1967c". In Hal Foster, Benjamin Buchloh, Yve-Alain and Rosalind Krauss. Art Since 1900. Modernism. Antimodernism. Postmodernism. London: Thames \& Hudson, 2004, "515-520". 
Crispiani, Alejandro. Objetos para transformar el mundo: trayectorias del arte concreto-invencion: Argentina y Chile, 1940-1970. Santiago, Chile: Ediciones ARQ, 2011.

De Campos, Augusto. "A Moeda Concreta da Fala" [1957], in Teoria da Poesia Concreta -- Textos críticos e manifestos, 1950-1960. Sâo Pãulo: Edições Invenção, 1965, 109-120.

De Campos, Haroldo. "The Rule of Anthropophagy: Europe under the Sign of Devoration". Translated by Maria Tai Wolff, Latin American Literary Review, 14, 27 (1986), 42-60.

Elsen, Albert E. Modern European Sculpture 1918-1945: Unknown Beings and Other Realities. New York: Braziller, 1979.

Fischer, Kai. "Processes and Production: Observations on the Sculptures of Hans Arp 1929-2012" in Arie Hartog, ed. Hans Arp/Jean Arp. Sculptures, Hans Arp/Jean Arp. Sculptures: A Critical Study (Ostfildern: Hatje Cantz, 2012), 14-41. Galison Peter. "Concrete Abstraction", in Leah Dickerman ed. Inventing Abstraction, 1910-1925: How a Radical Idea Changed Art, New York, Museum of Modern Art, 2012, 350-57.

Geometric Abstraction: Latin American Art from the Patricia Phelps de Cisneros Collection. Cambridge, MA: Harvard University Art Museums, 2001.

Giedion-Welcker, Carola. Jean Arp. New York: Abrams, 1957.

Glazer, Bruce. 'Questions to Stella and Judd', in Art News (September 1966); reprinted in Minimal Art: A Critical Anthology, ed. Gregory Battcock (Berkeley, CA: University of California Press, 1995), 148-9.

Gomringer, Eugen. 'Max Bill und die Konkrete Dichtung'. In Gomringer ed. Festschrift zum 50. Geburtstag von Max Bill. Teufen: Niggli, 1958, 56-62. Gomringer, Eugen. Zur Sache der Konkreten: Eine Auswahl von Texten und Reden über Künstler und Gestaltungsfragen 1958-2000, 3 vols (Vienna: Splitter, 2000).

Gregory, F. G. "Form in Plants". In Lancelot Law Whyte ed. Aspects of Form, Bloomington: Indiana University Press, 1966, 57-86.

Harris, Steven. "Voluntary and Involuntary Sculpture". In Anna Dezeuze and Julia Kelly. Found Photography from Surrealism to Contemporary Art. Farnham: Ashgate, 2013, 13-38.

Hélion, Jean. 'Art Concret 1930: Four Painters and a Magazine', Translated by Jacqueline Ventadour, Art and Literature 11 (Winter 1967), pp. 128-133. Hélion, Jean. 'Les Problèmes de l'art Concret: Art et Mathématiques', in Art Concret (1930), 5-10.

Hoffmann, Tobias. Die Idee Konkret: Konkrete Kunst als Ideengeschichtliche Entwicklung. Ingolstadt: Museum für konkrete Kunst, 2012.

Hüttinger, Eduard. Max Bill. Zurich: abc, 1978.

Jobse, Jonneke. De Stijl Continued: The Journal Structure (1958-1964): An Artists' Debate. Rotterdam: 010, 2005.

Lemoine, Serge. Art Concret. Mouans-Sartoux: Espace de l'Art Concret, 2000. Marchioiri, Giuseppe. Arp. Milan: Bruno Alfieri, 1964.

Margherita Andreotti, The Early Sculptures of Jean Arp. Ann Arbor: UMI Research Press, 1989.

Merklinger, Martina. Die Biennale São Paulo: Kulturaustausch zwischen Brazilien und der jungen Bundesrepublik Deutschland (1949-1954). Bielefeld: Transcript, 2013 
Olea, Héctor. "A Weekly Dose of Theory in the Papers: Ferreira Gullar and the Jornal do Brasil Sunday Supplement", in Building on A Construct: The Adolpho Leirner Collection of Brazilian Constructive Art at the Museum of Fine Art, Houston, ed. Mari Carmen Ramírez and Héctor Olea. Houston, Museum of Fine Arts, 2009, 215-234.

Perrone, Charles A. Seven Faces: Brazilian Poetry since Modernism. Durham and London: Duke University Press, 1996.

Price, Rachel. "Object, non-object, trans-object, relational object: from Concrete Poetry to the nova objetividade". Revista de Letras, 47, 1, Haroldo de Campos (Jan. - June 2007), 31-50.

Price, Rachel. The Object of the Atlantic: Concrete Aesthetics in Cuba, Brazil, and Spain, 1868-1968. Evanston, IL: Northwestern University Press, 2014.

Radanowicz, Georg, dir. 22 Fragen an Max Bill. 1969 (film)

Ramírez, Mari Carmen and Héctor Olea, eds. Inverted Utopias: Avant-Garde Art in Latin America. New Haven and London: Yale University Press, 2004. Ramírez, Mari Carmen. "Between corpus solidum and quasi-corpus: Colour in Concretismo and Neoconcretismo", Building on A Construct: The Adolpho Leirner Collection of Brazilian Constructive Art at the Museum of Fine Art, Houston, ed. Mari Carmen Ramírez and Héctor Olea. Houston, Museum of Fine Arts, 2009, 271-291.

Read, Herbert. The Art of Jean Arp. New York: Abrams, 1968.

Rubin, William S. Dada, Surrealism, and their Heritage. New York: Museum of Modern Art, 1967.

Schaeffer, Pierre. In Search of a Concrete Music (Berkeley, CA: University of California Press, 2012).

Solt, Mary Ellen. Concrete Poetry: A World View. Bloomington: Indiana University Press, 1970.

Taylor, Brandon. After Constructivism. New Haven and London: Yale University Press, 2014.

Thomas, Angela. "Aus der bewegten Geschichte der internationalen Künstlervereinigung Abstraction Création, Paris, 1931-1937". in Für eine neue Welt: Georges Vantongerloo und seine Kreise von Mondrian bis Bill, ed.

Christoph Brockhaus and Hans Janssen. Zürich: Scheidegger \& Spiess, 2009, 227242.

Van Doesburg, Theo, Otto Carlsund, Jean Hélion, Léon Tutundjian, Marcel Wantz, Art Concret (1930).

Van Doesburg, Theo. 'Définitions de l'art selon Doesbourg', Art Concret, p. 12. Vilyams, Petr, B. Volkov, Konstantin Vyalov, V. Lyushin, and Y. Merkulov, 'Concretists', in 'Statements from the Catalogue of the "First Discussional Exhibition of Associations of Active Revolutionary Art"'. In John E. Bowlt ed. Russian Art of the Avant-Garde. London: Thames \& Hudson, 1988, 240 von Asten, Astrid. "Concretions". In Hans Arp. Die Natur der Dinge. Translated by Steven Lindberg, Rolandseck: Arp Museum, 2007, 148-51. 
Alistair Rider teaches at the School of Art History, University of St Andrews. His research commitments relate to the art and visual cultures of the 1950s, 1960s and 1970s. He is particularly interested in the legacies of abstraction, theories of sculpture, and artist-led political activism. He is the author of Carl Andre: Things in their Elements (2011).

$\underline{\text { Mailing addresses }}$

Before 12 July 2014

Alistair Rider

c/o Linda Goddard

School of Historical Studies

Institute for Advanced Study

Einstein Drive

Princeton

NJ 08540

USA

After 12 July 2014

Alistair Rider

School of Art History

University of St Andrews

79 North Street

St Andrews

Fife KY16 9AL 